\title{
Modalidades interpeladoras do fazer crítico
}

\author{
Maria Helena Serôdio
}

Equacionar a crítica de teatro como "agente de intervenção sobre o presente e de instrumento ao serviço da memória", como escrevem Paulo Eduardo Carvalho e Sebastiana

Fadda na abertura do "Dossiê temático" deste número da revista, equivale a interpelá-la em função do que têm sido as mais recentes interrogações que se colocam a essa actividade heuristica no seu enquadramento mais geral: de competências exigiveis a quem a exerce, de possibilidades de real exercício nos seus diversos suportes e lugares, de desafio colocado às instâncias e linguagens artísticas que operam no plano da criação e incitam a análises cada vez mais exigentes (pelos saberes e técnicas que mobilizam), de irradiante problematização do cultural na sua mais geral incidência.

No plano internacional - a que mais directamente se liga a APCT - esta problemática foi questionada no XXII Congresso da Associação Internacional de Críticos de Teatro (Março de 2006, em Turim) sob o título algo provocatório "0 fim da crítica?" e dele derivaram três dos artigos aqui reproduzidos em tradução. Se em português pode ser ambíguo o termo - significando "término" e "finalidade" -, em inglês e francês a expressão empurra, de forma mais enérgica, para uma interrogação sobre a sua viabilidade hoje. É para essas valências que procurámos respostas, alargando ainda a interrogação a alguns dos críticos que em Portugal se debruçam sobre as artes performativas em geral para sabermos o que pensariam sobre estas questões num quadro de alargadas modalidades do fazer crítico.

Como interrogação, sabemos que tem atravessado vários tempos e lugares e tem concitado as mais amplas reflexões, não apenas em função da sua estrita efectivação no campo da academia (nos Estudos de Teatro, de acordo com a mais recente cartografia de Patrice Pavis (2000) ou Erika Fischer-Lichte (2003)) e dos media (a ponto de integrar novas formulações na Internet, por exemplo), mas também decorrentes das novas modalidades de pensar o teatro em função de visões teóricas que o realinham em diferentes perspectivas - antropológicas, sociológicas, psicológicas, filosóficas, etc. - e dos próprios modos de percepção que foram entrando no nosso quotidiano e "afectando" a nossa relação com a arte em geral, e o teatro em particular, por razões tecnológicas, sociais e culturais, entre outras.

0 exercício reflexivo que temos vindo a praticar de diferentes maneiras nesta revista prende-se com a pluralidade de agenciamentos que reconhecemos no campo das artes performativas, mas também com as modalidades diversas de as percepcionar, investigar, analisar e avaliar. Defendemos em Turim, no quadro deste debate sobre a crítica, a ideia de que gostaríamos de importar para a nossa prática nesta revista a poderosa metáfora do rizoma que Gilles Deleuze e Felix Guattari usam em Mille plateaux, um cenário intelectual descentrado, agindo através de uma diversidade de tópicos ou "plateaux", de acordo com a definição por eles avançada: "Un plateau est toujours au milieu, ni début ni fin. Un rhizome est fait de plateaux" (1980: 2). Ou: "Un rhizome ne commence et n'aboutit pas, il est toujours au milieu, entre les choses, inter-être, intermezzo" (Ibidem: 36$)$.

Essa diversidade - que se concretiza nas várias secções (com que fixámos a sua estrutura) e nas diversas colaborações nacionais e internacionais que aqui recolhemos - reenvia para objectos vários que ocupam o nosso horizonte de análise e reflexão, ao mesmo tempo que enuncia modos diversos de as praticarmos. De fora chegamnos estudos informados sobre temáticas e autores de candente actualidade ou de persistente interrogação, como é o caso de Samuel Beckett (por Christopher Murray, um notável estudioso de teatro da Universidade de Dublin), de Harold Pinter (por um dos directores da Pinter Review, Frank Gillen, da Universidade de Tampa, Florida) e de uma questionação sobre modos de funcionamento do teatro na polis grega (por Donato Loscalzo, da Universidade del Molise, Itália) ocupando os três artigos a secção "Estudos aplicados". Mas de fora vêm também visões de críticos portugueses - como Ana Pais, Paulo Trindade e Rita Martins - dando testemunho da sua participação em fóruns e festivais internacionais, coincidindo nos dois últimos casos com a frequência de Seminários para Jovens Críticos. Realizados no âmbito da Associação Internacional de Críticos de Teatro, estes seminários correspondem a uma das prioridades da actuação da APCT, que neles vem apostando sistematicamente, quer enviando jovens críticos portugueses, quer organizando-os em território nacional (como já aconteceu em Almada, por duas vezes, e no Porto uma), quer ainda assegurando a direcção e/ou a docência em várias das suas edições. Foi, de resto, num desses seminários que decorreu no Porto em 2001 que participou o crítico Mark Brown que aqui nos fala das primeiras experiências do Teatro Nacional Escocês. Mas nas "Notícias de fora", em que se alinham estes artigos, cabe ainda um estudo sobre uma das companhias mais interessantes da Hungria - os Pintér Béla e Companhia, que, de resto, já se apresentou por duas vezes em Portugal - escrito por uma jovem interessada também na realidade cultural portuguesa. E, sendo ainda uma visita de fora, o espectáculo 
sobre texto de lonesco, que Emanuel Démarcy-Mota encenou para a Comédie de Reims, ocupa a atenção crítica na rubrica "Passos em volta" que analisa espectáculos que se apresentaram entre nós (sendo ou não produções portuguesas).

Do teatro em Portugal falam-nos Luiz Francisco Rebello e Rui Pina Coelho em importantes trabalhos de investigação histórica, respectivamente, sobre a recepção primeira de Ibsen entre nós (para a rubrica "Estudos aplicados"), e sobre a Casa da Comédia (para o "Arquivo solto"), neste caso, decorrente da aturada pesquisa feita para a sua tese de mestrado em Estudos de Teatro apresentada à Faculdade de Letras de Lisboa. Por sua vez, e em voz própria, Lúcia Sigalho fala "Na primeira pessoa" do seu percurso artístico e das interrogações que se the colocam hoje no âmbito da Sensurround e da Casa D'Os Dias da Água, enquanto Rogério de Carvalho é relembrado no "Portefólio" quer em texto introdutório de Paulo Eduardo Carvalho, quer por um conjunto de fotografias que recordam alguns dos muitos espectáculos de que foi oficiante maior.

É ainda sobre a realidade teatral portuguesa que a jovem investigadora Paula Cristina Gomes fala, abordando o tópico dos sítios na Internet de algumas companhias para a rubrica "Em rede", enquanto nos "Passos em volta" nos surgem análises de espectáculos apresentados no âmbito do Festival Alkantara, ou por companhias tão diversas como o Teatro Meridional, a Comuna, a Companhia de Teatro de Almada e o Teatro Plástico.

De entre alguns dos livros recentemente publicados entre nós, a rubrica "Leituras" anota criticamente um estudo sobre a recepção de Shakespeare pelos românticos portugueses, mas também dá conta de iniciativas editoriais ligadas a práticas artísticas, quer no contexto do Centro de Estudos de Novas Tendências Artisticas, em Vila Velha de Ródão, e da Transforma AC, de Torres Vedras, quer a partir de uma curiosa publicação das Visões Úteis.

Uma tão alargada visão do que se vai fazendo em palco e interpelando criticamente nas várias linguagens e suportes, que existem hoje ao dispor da investigação e reflexão crítica, implica um denodado esforço de todos quantos aqui quiseram colaborar de forma entusiasta e generosa. Que contaram, de resto, com o apoio dos que - no campo artístico e documental - dispensaram fotografias, desfizeram dúvidas e colaboraram na procura de documentação (aqui com um destacado protagonismo por parte de quem trabalha no Museu Nacional de Teatro). E não é fácil aceitar que este esforço - de quem faz teatro e de quem o estuda - raras vezes veja o seu empenhamento premiado ou sequer reconhecido.

Pelo lado da revista, salientamos o apoio que o Instituto Português do Livro e das Bibliotecas nos concedeu por mais um ano (expresso na compra de exemplares para as Bibliotecas Municipais e que, por desencontro de datas, não veio expressamente referido no nosso número 5), bem como a solidariedade indefectivel do Instituto Camões e a publicidade que o Teatro Nacional D. Maria II e o Teatro Nacional S. João aceitaram incluir neste número. É, porém, ainda tão pouco relativamente ao que de facto "custa" esta publicação que receamos não ter condições para continuar por muito mais tempo. Seria, certamente, uma pena não prosseguir um esforço que congrega tantas vontades, se exerce de forma tão exigente e responsável, e dá voz a muitos dos que se afadigam - gostosamente - a estudar o que em teatro se pensa e se vai fazendo aqui e no resto do mundo... Mas o desinteresse pelas coisas da cultura está hoje de tal modo implantado em círculos políticos e mediáticos, que lhes parece dispensável de todo a criação artística sobretudo no campo do teatro. Do Porto vieram factos, declarações e imagens que documentam de forma eloquente essa opção de alienar o que era sentido como lugar de serviço público e que teve o seu triste desfecho no que se passou no Teatro Rivoli, aqui suspeitado já no texto que Constança Carvalho Homem assina. Mas essa é, infelizmente, a norma em muitas instâncias e não pode deixar de preocupar quem acredita que o teatro faz parte integrante e vital da criação cultural de um pais.

\section{Referências bibliográficas}

DELEUZE, Gilles / GUATTARI, Félix (1980), Mille plateaux, Paris, Éditions de Minuit.

FISCHER-LICHTE, Erika (2003), "Ouo vadis? Theatre Studies at the Crossroads", Modern Drama: Defining the Field, ed. Ric Knowles, Joanne Tompkins \& W. B. Worthen, Toronto, Buffalo, London, University of Toronto Press, pp. 48-66.

PAVIS, Patrice (2000), "Les études théâtrales et l'interdisciplinarité", in Vers une théorie de la pratique théâtrale: Voix et images de la scène, Villeneuve-dAscq, Presses Universitaires du Septentrion. 